\title{
Marked Increase in $\beta$-Tubulin mRNA Expression during Regeneration of Axotomized Retinal Ganglion Cells in Adult Mammals
}

\author{
Lisa McKerracher, Charles Essagian, and Albert J. Aguayo \\ Centre for Research in Neuroscience, Montreal General Hospital Research Institute and McGill University, Montreal, \\ Quebec, H3G 1 A4 Canada
}

Changes in gene expression were investigated in axotomized CNS neurons under conditions that inhibit or permit regrowth of their damaged axons. Levels of MRNA encoding $\beta$-tubulin, the $150 \mathrm{kDa}$ neurofilament subunit (NF-M), and glyceraldehyde-3-phosphate dehydrogenase (GAPDH) were examined by quantitative in situ hybridization of adult rat retinal ganglion cells (RGCs) after axotomy in the optic nerve or during regeneration in a peripheral nerve (PN) graft. Soon after optic nerve section $\beta$-tubulin, NF-M, and GAPDH mRNA levels decreased and remained low during the 1 month studied. In these retinas $\beta$-tubulin mRNA fell to approximately $\mathbf{5 0 \%}$ of normal controls. However, in the PN-grafted retinas, where approximately $20 \%$ of the surviving axotomized RGCs regenerate their axons, there were "hot spots" of $\beta$-tubulin mRNAs where neuronal levels were nearly $300 \%$ higher than in controls. By retrograde neuronal labeling these hot spots were shown to correspond to the injured RGCs that regrew their axons into the PN graft; $\boldsymbol{\beta}$-tubulin mRNA levels in nonregenerating RGCs of the same retinas averaged $63 \%$ of controls. We suggest that interactions of RGC axons and components of the grafts' non-neuronal environment play a key role in the over fourfold differences in $\beta$-tubulin mRNA levels observed between injured and regenerating RGCs.

[Key words: CNS, nerve regeneration, gene expression, tubulin, neurofilament, axotomy, peripheral nerve graft, retinal ganglion cell]

An increase in the mRNA levels that encode for tubulin is a consistent finding in nerve cells whose axons regenerate in mammalian peripheral nerves (PNs) or in the optic nerves of fish and amphibians (Grafstein, 1986; Hoffman and Cleveland, 1988; Miller et al., 1989; Mizobuchi et al., 1990; Tetzlaff et al., 1991). Conversely, in the CNS of adult mammals, where axonal regeneration is normally aborted, tubulin mRNAs drop and remain low after injury (Mikucki and Oblinger, 1991; Tetzlaff et al., 1991; McKerracher et al., 1993).

\footnotetext{
Received Mar. 2, 1993; revised June 11, 1993; accepted June 17, 1993.

We thank Paul Jones for helpful comments, Nahum Sonenberg (Department of Biochemistry, McGill University) for providing the GAPDH probe, and YiChun Wang and Manuel Vidal-Sanz for preparing the PN-grafted animals. We gratefully acknowledge NSERC and FRSQ for financial support to L.M.; A.J.A. was supported by grants from the MRC of Canada and the Multiple Sclerosis Society of Canada. We are members of the Canadian Network of Centers for the study of Neural Regeneration.

Correspondence should be addressed to Dr. Lisa McKerracher, Centre for Research in Neuroscience, Montreal General Hospital, 1650 Cedar Avenue, Montreal. Ouebec. H3G IA4 Canada.

Copyright (C) 1993 Society for Neuroscience $0270-6474 / 93 / 135294-07 \$ 05.00 / 0$
}

In retinal ganglion cells (RGCs) whose axons are severed intracranially in the optic nerve, the fall in tubulin mRNAs is paralleled by a marked decrease in the rate of slow axonal transport (McKerracher et al., 1990b). In these CNS neurons both the slower transport rate and the fall in tubulin mRNAs occur approximately 1 week after axotomy, whereas the expression of neurofilament (NF) mRNAs is reduced soon after injury. Decreases in the expression of NFs, therefore, appear to be an early feature of the neuronal response to injury that is common to all nerve cells axotomized in the PNS or CNS (Hoffman et al., 1987; Verge et al., 1990; Wong and Oblinger, 1991). In contrast, a drop in the total tubulin mRNA levels has only been observed following axonal injury in the CNS (Mikucki and Oblinger, 1991; Tetzlaff et al., 1991; McKerracher et al., 1993).

While axotomized RGCs do not normally regrow their axons in the optic nerve of rodents, they can extend long distances and make functional connections in the tectum when the glial environment of the optic nerve is substituted for a PN graft (Aguayo et al., 1991). In these animals, the transport rates of tubulin and NF double when the axotomized RGCs regenerate axons into the PN grafts, a change that contrasts with the 10 fold slowing of these rates in the ocular stump of severed optic nerves (McKerracher et al., 1990a,b). Thus, injured CNS neurons in these adult mammals appear to be capable of diverse regulatory changes after injury and during regrowth.

To investigate further the capacities of adult mammalian CNS neurons to change gene expression in response to interactions with different growth-cone environments, we have now examined mRNA levels for the cytoskeletal proteins $\beta$-tubulin and the $150 \mathrm{kDa}$ NF subunit (NF-M) under conditions that inhibit or facilitate the regrowth of their interrupted axons. Variations in $\beta$-tubulin and NF-M expression were compared to changes in mRNA levels of glyceraldehyde-3-phosphate dehydrogenase (GAPDH), a protein involved in glycolysis.

\section{Materials and Methods}

Surgery and tissue preparation. Adult female Sprague-Dawley rats (180$220 \mathrm{gm}$ ) were anesthetized by an intraperitoneal injection of chloral hydrate $(0.42 \mathrm{mg} / \mathrm{gm}$ body weight). The left optic nerve was transected intraorbitally $0.5 \mathrm{~mm}$ from the eye (Vidal-Sanz et al., 1987) and the axotomized and contralateral retinas were compared at $18 \mathrm{hr}(n=3$ animals), $2 \mathrm{~d}(n=2), 1$ week $(n=2), 10 \mathrm{~d}(n=1), 2$ weeks $(n=2)$, or 1 month $(n=2)$ after surgery. In four animals an autologous PN graft was sutured to the optic nerve stump (Vidal-Sanz et al., 1987). In two of these animals crystals of the retrograde tracer Dil (Vidal-Sanz et al., 1988) were gently inserted at multiple sites in the mid and distal regions of the graft 1 week after grafting, to label regrowing RGCs passively. The application of the tracer to the graft at this early time was aimed at avoiding changes in gene expression likely to occur if regrowing axons were injured by the standard procedures used to apply tracers. The 


\section{Control}
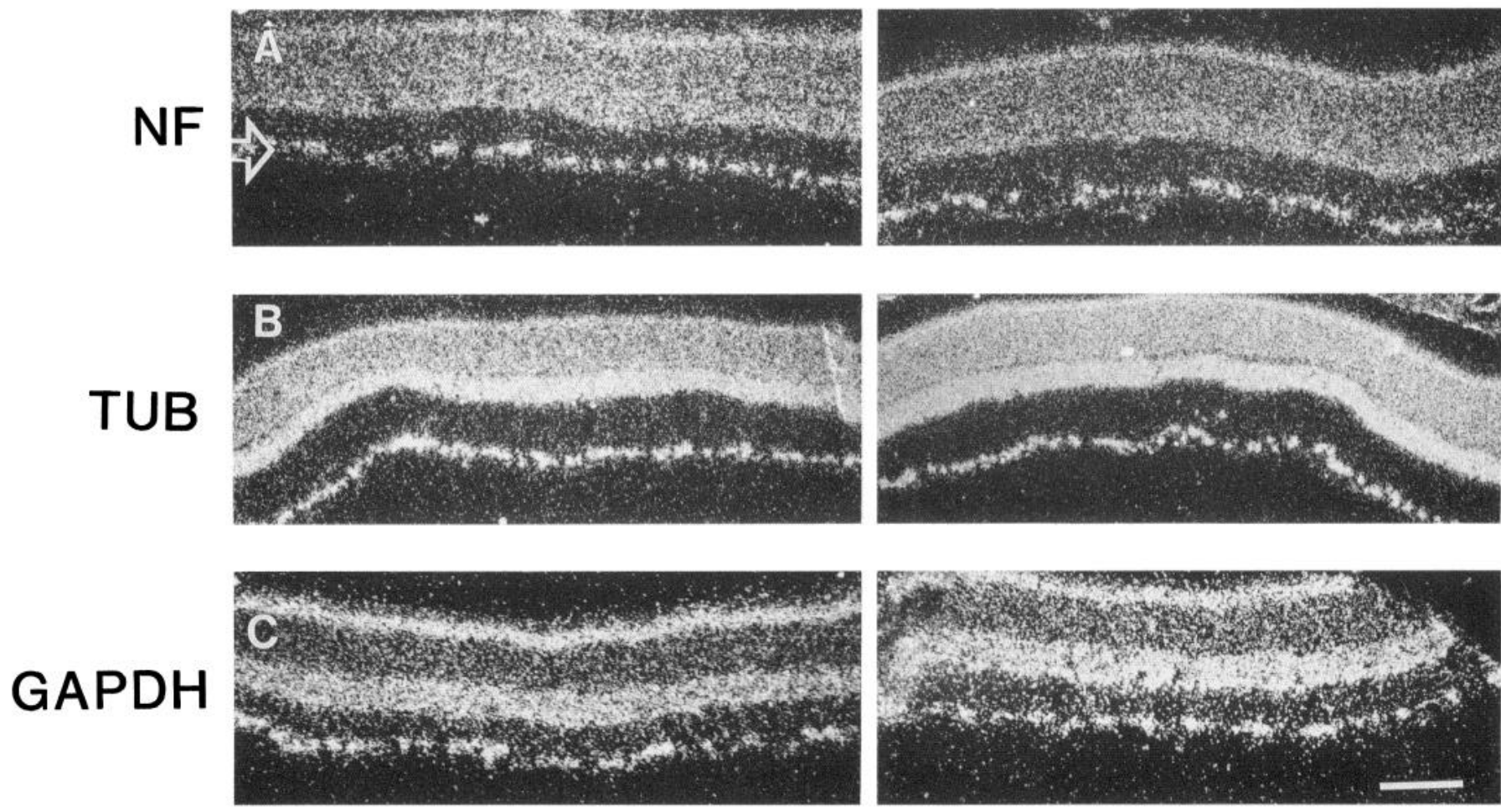

Axotomized
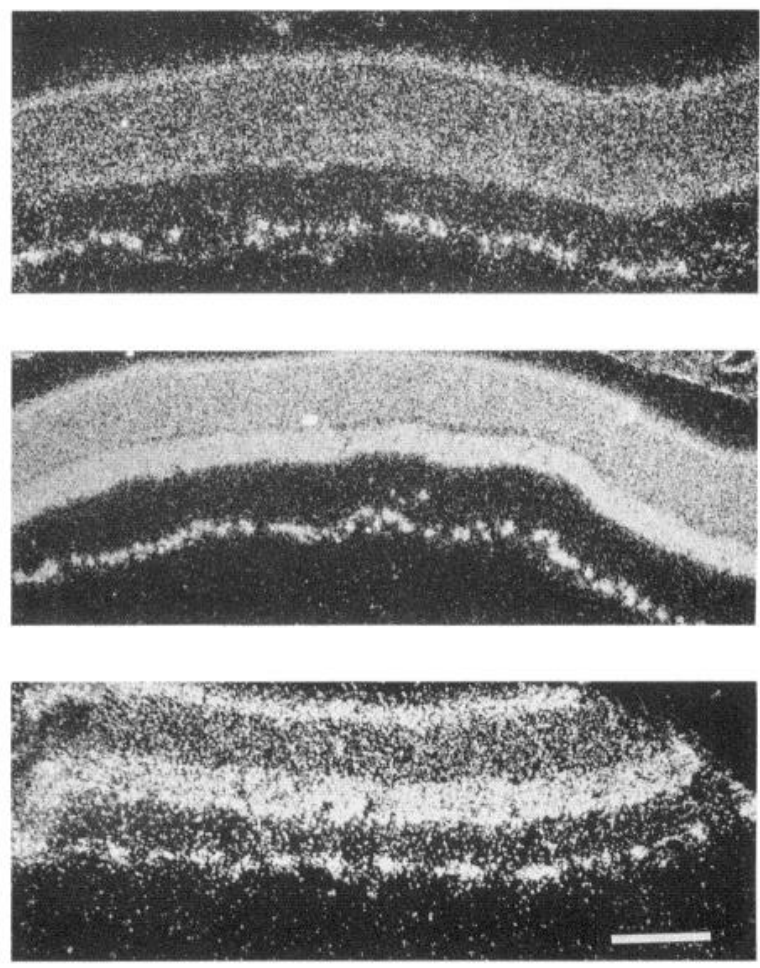

Figure 1. Dark-field micrographs of radial sections from the uninjured control (left) and 1 week axotomized (right) retinas probed with $\beta$-tubulin $(A)$, NF-M $(B)$, or GAPDH $(C)$. The RGC layer is indicated in $A$ by an arrow. At this time only slight differences are observed when control and injured retinas are compared. Scale bar, $100 \mu \mathrm{m}$.

grafted and contralateral retinas were compared 21-25 $\mathrm{d}$ after inserting the PN graft, a time when the RGC axons are actively growing along the graft (McKerracher et al., 1990a). For all animals, both eyes were removed under anesthesia and immediately immersed in $4 \%$ paraformaldehyde, $0.1 \mathrm{~m}$ phosphate buffer, $\mathrm{pH} 7.2$, after perforating the cornea. After approximately $15 \mathrm{~min}$ the cornea and lens were dissected away, and fixation continued for a further 2-3 hr. The eyes were washed in PBS, soaked in $10 \%$ sucrose in PBS overnight, and then cut in half, and the left and right pairs were frozen together in Tissue Tek O.C.T. (Canlab, Montreal, Quebec) by immersion in isopentane at $-60^{\circ} \mathrm{C}$ to $-80^{\circ} \mathrm{C}$. The samples were wrapped in parafilm and stored at $-80^{\circ} \mathrm{C}$ before cutting radial cryostat sections of $8-10 \mu \mathrm{m}$ thickness.

In situ hybridization. A 750 base pair (bp) cDNA fragment (McKerracher et al., 1993) of the $m \beta 5$ tubulin gene (Lewis et al., 1985) and a 660 bp cDNA fragment of the NF-M gene (Julien et al., 1986), both in Bluescript vectors, were used to make ${ }^{35} \mathrm{~S}$-labeled RNA probes by in vitro transcription with a kit from Stratagene (La Jolla, CA). A GAPDH cDNA clone of approximately 1400 bp (Piechaczyk et al., 1984) was used to generate ${ }^{35} \mathrm{~S}$-labeled cDNA probes with an oligolabeling kit from Pharmacia (Montreal, Quebec, Canada). The paired axotomized and contralateral retinas were sectioned and processed together for in situ hybridization (McKerracher et al., 1993). With the GAPDH cDNA probes, the washing temperature was reduced to $45^{\circ} \mathrm{C}$ and the RNase treatment was omitted.

Quantitative analysis. An Image 1 (Universal Imaging Corp., West Chester, PA) image analysis system was used to count the number of autoradiographic silver grains over the cells in the RGC layer of each pair of axotomized and contralateral retinas stained with cresyl violet (McKerracher et al., 1993). The estimated average grain size was 0.2 $\mu \mathrm{m}$, a value that was used to calculate the number of grains in fused grain tracks. The autoradiographic grains per cell were counted to determine a labeling index independent of cell size. A cell size cutoff of $70 \mu \mathrm{m}^{2}$ was used to exclude the smaller amacrine cell from the analysis of labeling in the RGC layer of the retina. The average number of grains per RGC was calculated for each retina, and the values for the axotom- ized retinas were expressed as a percentage of the respective contralateral intact retina (axotomized/contralateral $\times 100$ ).

\section{Results}

\section{mRNA expression after axotomy}

In situ hybridization of normal, unoperated retinas showed strong hybridization of the $\beta$-tubulin, NF-M, and GAPDH probes to the RGC layer of the retina, with labeling concentrated over the neuronal somata. The grain distribution in the RGC layer of axotomized retinas was compared by dark-field microscopy to that of the intact retinas. One week after axotomy the signal intensity of all three probes fell slightly in the RGC layer of the injured retinas (Fig. 1), but by 1 month after such injury the hybridization signal over this layer was clearly less than in controls (e.g., Fig. 2). Because the RGCs make up only $50 \%$ of the nerve cells in the RGC layer (Perry, 1981) and approximately $80 \%$ of RGCs die within 2 weeks of optic nerve transection 0.5 $\mathrm{mm}$ from the eye (Villegas-Perez et al., 1993), we investigated if the overall fall in mRNAs was due solely to cell loss or also to a decrease in the expression of these genes in the individual RGCs. For this purpose the number of grains per RGC layer neuron was estimated in the axotomized and intact contralateral retinas. Since the displaced amacrine cells that also populate the RGC layer are smaller than the RGCs (Perry, 1981; VillegasPerez et al., 1988), we confined our analysis to the RGC layer neurons larger than $70 \mu \mathrm{m}^{2}$ (Villegas-Perez et al., 1988). In the sections of intact control retinas prepared for in situ hybridization, approximately $45 \%$ of the RGC layer cells were found to be $70 \mu \mathrm{m}^{2}$ or larger. The average number of grains of both $\beta$-tu- 

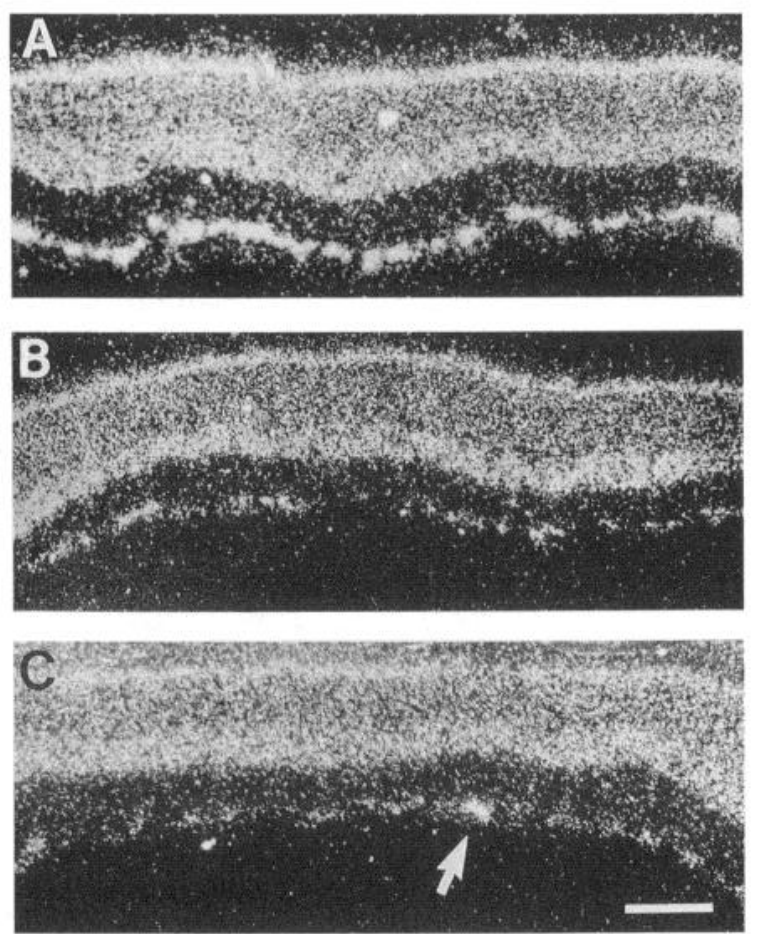

Figure 2. Hybridization of $\beta$-tubulin mRNA to axotomized and PNgrafted retinas: dark-field micrographs of radial sections from an uninjured control $(A)$ and an experimental retina whose RGC axons were severed a month earlier $(B)$. The signal intensity is reduced in the RGC layer of the injured retina. In a PN-grafted retina $(C)$ where the signal intensity is also generally reduced, a single "hot spot" (arrow) is seen in the RGC layer. Scale bar, $100 \mu \mathrm{m}$.

bulin and NF-M counted over individual RGCs decreased during the first week after axotomy (Fig. 3). One month after axotomy the mRNA levels for $\beta$-tubulin and NF-M in the injured RGCs remained low at $50 \%$ and $60 \%$ of the respective control levels (Fig. 3).

\section{mRNA expression in PN-grafted retinas}

It has been previously established that approximately $20 \%$ of the surviving RGCs regenerate an axon when the cut optic nerve is substituted by a PN graft attached to the eye (Villegas-Perez et al., 1988). In the present experiments we examined PN-grafted retinas 20-25 d after axotomy and grafting, a time when regenerating RGC axons are known to approach the caudal end of the $3 \mathrm{~cm}$ PN grafts (McKerracher et al., 1990a).

Grain counts from these retinas showed an overall decrease in both NF-M and $\beta$-tubulin mRNAs. The mRNA level for NF-M fell in both PN-grafted and axotomized retinas to approximately one-half of control values (Fig. $3 B$ ). However, in the PN-grafted retinas probed with $\beta$-tubulin RNA, there were distinct "hot spots" of intensely labeled single RGCs (Figs. $2 C$, $5)$. The number of grains counted in these hot spots was nearly threefold higher (286\%) than that over the RGCs of the intact retinas. To ascertain if such hot spots represented RGCs with axons regenerating in the PN graft or nonregenerating RGCs whose levels of $\beta$-tubulin mRNAs were enhanced by the presence of the PN graft, RGC somata were retrogradely labeled with the neuronal tracer DiI applied to the distal portions of the graft. It was found that RGCs that were labeled as a result of the regrowth of their axons into the PN grafts were responsible for the strong hybridization signals for $\beta$-tubulin mRNA (Fig.

\section{A. Tubulin}

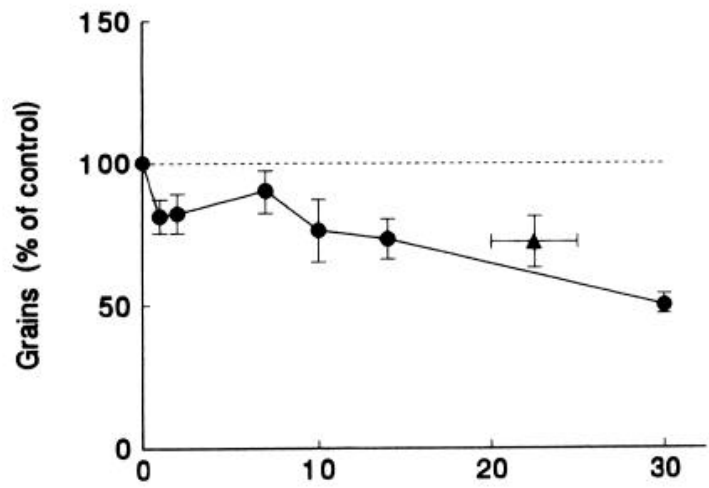

\section{B. NF-M}

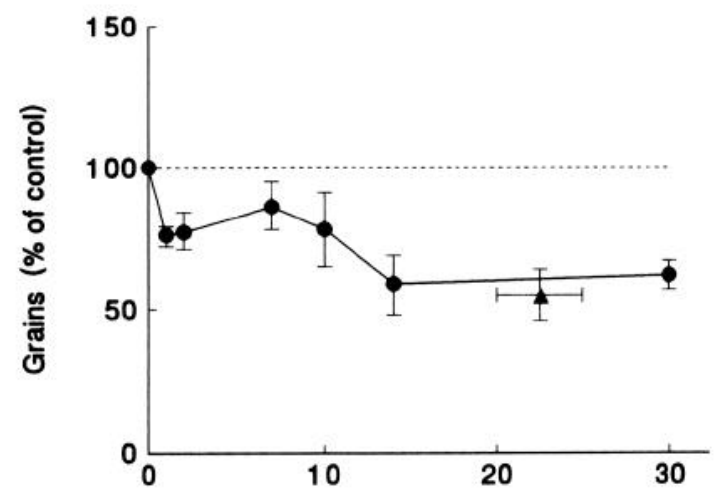

\section{GAPDH}

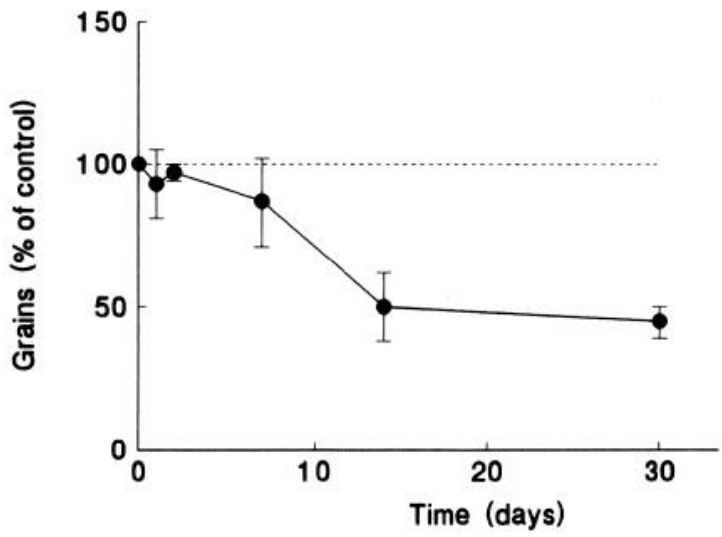

Figure 3. Estimates of $\beta$-tubulin, NF-M, and GAPDH mRNA expression from 1 to $30 \mathrm{~d}$ after optic nerve transection close to the eye. The axotomized retinas were examined at various times after optic nerve transection (circles) or PN grafting (triangles). Measurements from the PN-grafted retinas reflect values for all RGCs. Each point represents the mean \pm SEM from three to eight experiments. Average values indicate there is an early and gradual decline of all the mRNAs determined after injury. Values in the PN-grafted retinas do not differ significantly from those in the injured retinas with no PN grafts. 

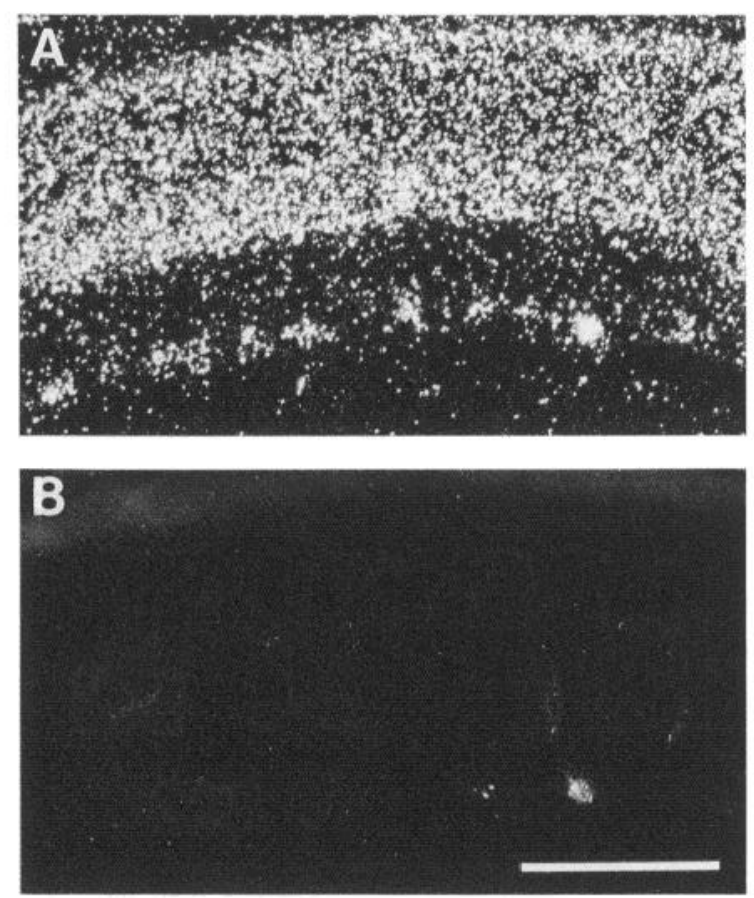

Figure 4. Correspondence between a $\beta$-tubulin hybridization hot spot $(A)$ and a DiI-labeled regenerating RGC $(B)$. The fluorescent image of the DiI-labeled cell was photographed with both epifluorescent and phase-contrast illumination to confirm the position of the cell in the PN-grafted retina before and after in situ hybridization. Scale bar, 100 $\mu \mathrm{m}$.

4). In the PN-grafted retinas where grains overlaying all RGCs (including the hot spots) were counted, the average mRNA level was $73 \%$ of the control value (Fig. $3 A$ ). When counts from the RGC hot spots were subtracted from this data the $\beta$-tubulin level in the presumably nonregenerating RGCs was $63 \%$ of controls (Fig. 6). This value was not statistically different from the $\beta$-tubulin mRNA levels of the 2 week or 1 month axotomized RGCs of retinas with no PN grafts (Fig. 6).

\section{GAPDH expression after axotomy}

To examine whether the reduced $\beta$-tubulin and NF-M mRNA levels detected after optic nerve transection represent specific changes in the expression of cytoskeletal proteins or a more general cellular response to injury in the absence of axonal growth, we examined how axotomy affected the mRNA level for the metabolic enzyme GAPDH. In the injured retinas the GAPDH mRNA level also fell to approximately $40 \%$ of the control values, 1 and 2 weeks after RGC axotomy (Fig. $3 C$ ). In the PNgrafted retinas the overall GAPDH mRNA levels decreased, but hot spots of intense hybridization were observed to correspond to regenerating RGCs.

\section{Discussion}

\section{Comparison of axotomized and $\mathrm{PN}$-grafted retinas}

In the present study neuronal mRNA levels were assessed by quantitative in situ hybridization of paired intact and axotomized, or intact and regenerating retinas. An overall decrease in $\beta$-tubulin and NF-M gene expression was observed in the injured retinas soon after the RGC axons were interrupted in the optic nerve. Between 3 and 4 weeks after injury the average values of both $\beta$-tubulin and NF-M mRNAs estimated from
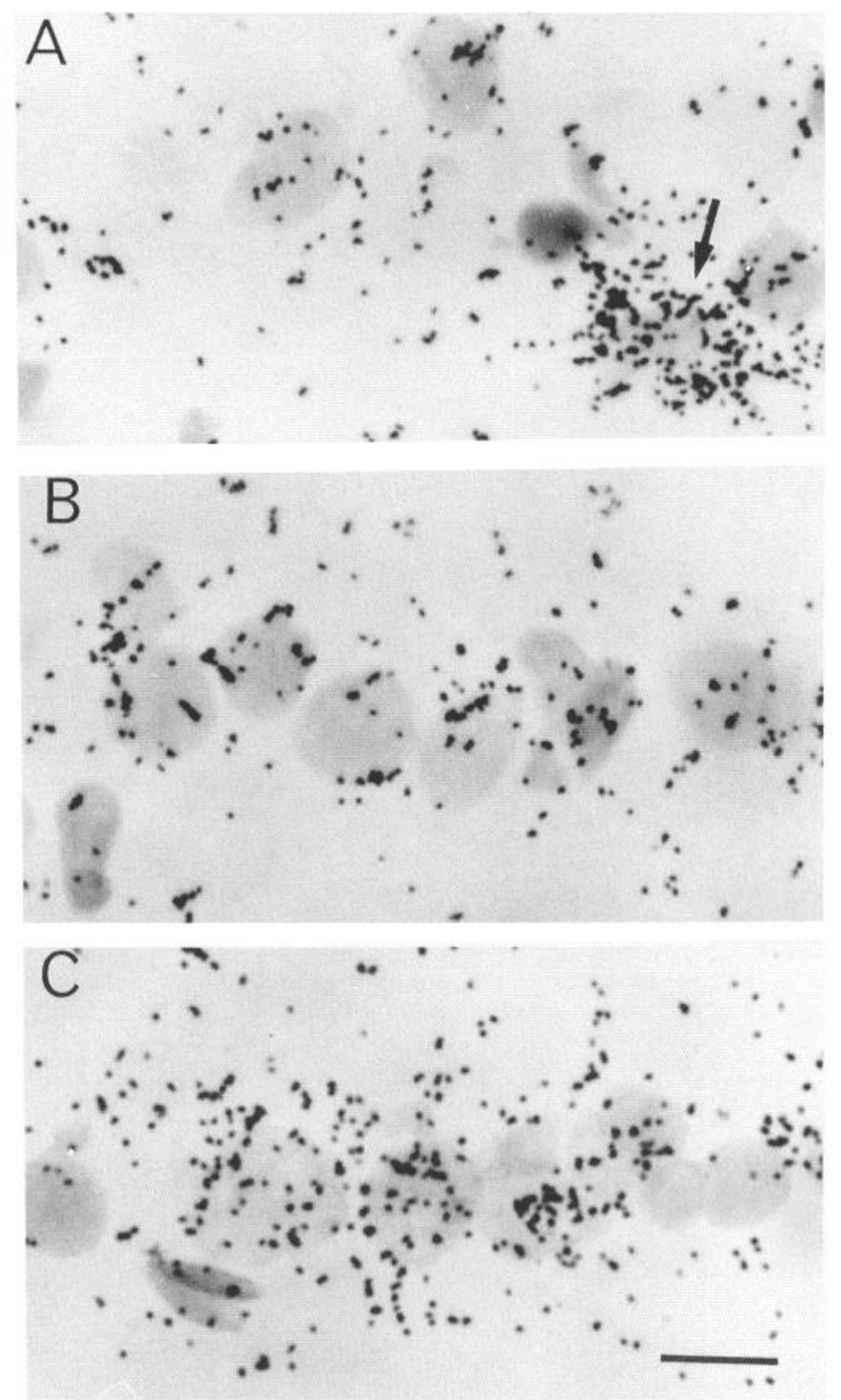

Figure 5. Bright-field micrographs of retinas hybridized with $\beta$-tubulin. $A$, A PN-grafted retina with a hybridization hot spot (arrow). $B$, Another region of the section shown in $A$ reveals few grains over other cells in the RGC layer. $C$, The contralateral intact retina processed on the same slide is shown for comparison. Scale bar, $10 \mu \mathrm{m}$.

grain counts over individual RGCs were, respectively, $50 \%$ and $60 \%$ of controls. However, in the PN-grafted retinas in which some of the RGCs regenerated an axon into a PN segment grafted to the ocular stump of the optic nerve (Villegas-Perez et al., 1988), there were distinct hot spots of increased $\beta$-tubulin and GAPDH mRNA expression. In these retinas there was, however, no increase in NF-M hybridization signals. By selectively labeling the soma of the RGCs whose axons had regrown into the PN grafts it was demonstrated that the $\beta$-tubulin and GAPDH mRNA hot spots corresponded to regenerating RGCs. While a clear correspondence between hot spots and labeled RGCs was observed, the histological conditions required for both the labeling and hybridization of retinal sections cannot exclude the possibility that some axotomized or regenerating RGCs respond differently to injury and regrowth.

Grain counts over the individual RGCs of the PN-grafted 
Figure 6. Changes in $\beta$-tubulin expression in axotomized and PN-grafted retinas. The $\beta$-tubulin mRNA levels in the hot spots are compared to those of other nonregenerating RGCs in the PNgrafted retinas. Values for axotomized RGCs in non-PN-grafted retinas are shown at 14 and $30 \mathrm{~d}$ after injury.

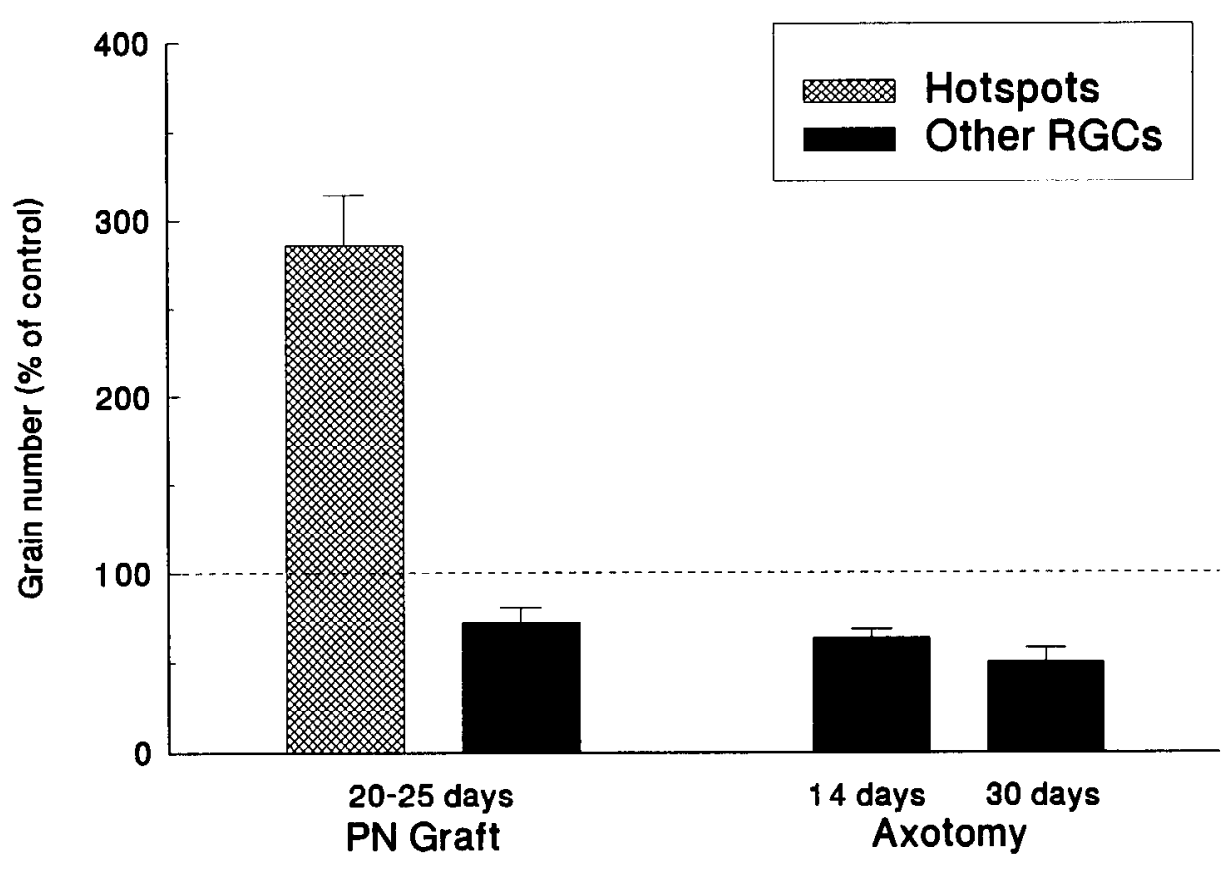

retinas examined by in situ hybridization indicated a striking difference (over fourfold) in the $\beta$-tubulin mRNA values expressed by axotomized RGCs that regenerated axons and by those RGCs that failed to grow into the grafts. Thus, the extension of RGC axons into the graft seems to be the main correlate of the upregulation of $\beta$-tubulin mRNAs in the injured RGCs. The rise in $\beta$-tubulin mRNAs and the persistent fall of the NF-M mRNAs observed in the RGCs supporting axonal regrowth resemble their patterns of expression in axotomized and regenerating nerve cells in the PNS (Hoffman et al., 1987; Hoffman and Cleveland, 1988; Verge et al., 1990; Tetzlaff et al., 1991; Wong and Oblinger, 1991) and in fish and amphibians (Grafstein, 1986; Mizobuchi et al., 1990). Conversely, these patterns are different from those previously documented in $\mathrm{RGCs}$ and other CNS neurons injured in the CNS where, after axotomy alone, both the tubulin and NF-M mRNAs fall (Mikucki and Oblinger, 1991; Tetzlaff et al., 1991; McKerracher et al., 1993).

While the key molecular events underlying the marked and disparate changes in $\beta$-tubulin expression after axotomy and during axonal regrowth are unknown, the present results in the rat retina suggest that interactions between axonal growth cones and the non-neuronal microenvironment in the optic nerve or PN graft may play a key role in signaling changes in gene expression. Such an interaction could involve nonreceptor tyrosine kinases that are thought to influence cell motility (Atashi et al., 1992; Zachary and Rozengurt, 1992) and are known to affect tubulin phosphorylation (Atashi et al., 1992).

Certain growth factors may also affect the expression of NF (Verge et al., 1990) and tubulin (Ma et al., 1992). While the nature of such influences remains unclear (Wong and Oblinger, 1991), Schwann cells that populate excised PN segments similar to those used here as PN grafts are an important source of trophic molecules such as brain-derived neurotrophic factor (Acheson et al., 1991; Meyer et al.,1992) and other growth factors (Heumann et al., 1987) that enhance RGC survival in vitro (Thanos et al., 1989) and in vivo (Mansour-Robaey et al., 1992). Although $\mathrm{PN}$ grafts have been shown to support the viability and regrowth of axotomized RGCs (Villegas-Perez et al., 1988), in the present experiments their apposition to the optic nerve stump does not appear to have resulted in a significant enhancement of the expression of these cytoskeletal mRNAs in RGCs whose axons failed to extend into the PN graft. It is not known if the lack of such an increase in $\beta$-tubulin mRNA indicates that putative molecules from the grafts do not directly influence $\beta$-tubulin gene expression in the injured RGCs, or if there is a limited diffusion of these molecules that reaches only a few of the RGC axonal stumps in the injured optic nerve. It is also possible that an early but transient increase in $\beta$-tubulin mRNA may have been no longer detectable at the times when the PN-grafted retinas were examined. At 20-25 d after the optic nerve of these animals was cut and anastomosed to the PN graft, RGC axons have already penetrated the graft, and the RGC axons in the graft would have direct access to diffusible factors and substrate components produced by graft components.

In the regenerating RGCs, signal transduction mechanisms mediated by interactions with substrate components or growth factors might result in either the transcriptional activation of tubulin, or changes in microtubule dynamics that affect the autoregulatory control of tubulin mRNA stability (Cleveland, 1988). While a transcriptional activation of distinct tubulin isotypes likely accompanies the regeneration of certain axons (Hoffman and Cleveland, 1988; Miller et al., 1989) it is also possible that a selective depletion of tubulin from the cell body by the accelerated transport rate of tubulin associated with axonal elongation into the PN grafts (McKerracher et al., 1990a) could signal the enhanced synthesis of $\beta$-tubulin mRNAs observed in the regenerating RGCs. Furthermore, adhesive interactions between growth cones and cell adhesion molecules may modulate tubulin phosphorylation through pp60 ${ }^{\text {c-src }}$ (Atashi et al., 1992), although it is not yet known how this and other nonreceptor protein tyrosine kinases (Zachary and Rozengurt, 1992) influence microtubule dynamics during neurite outgrowth. Our results suggest that axon elongation itself influences expression of tubulin in regrowing $\mathrm{RGCs}$. 
Possible implications of the downregulation of certain genes on the survival of axotomized $R G C s$

In the axotomized RGCs the GAPDH mRNA levels had markedly declined by 2 weeks after injury. Since there appears to be a good correlation between GAPDH protein and mRNA levels (Piechaczyk et al., 1984), a prolonged decrease in the production of energy by glycolysis may occur in all RGCs soon after axotomy. Persistent deficits in phosphate-bound energy and in the synthesis and transport of proteins such as tubulin may contribute to the protracted loss of injured RGCs documented after optic nerve injury (Villegas-Perez et al., 1988, 1993).

\section{Distance of the lesion from the cell soma and the expression of} $N F-M$ and $\beta$-tubulin

An immediate but transient increase (less than onefold) followed by a persistent drop in $\beta$-tubulin mRNA levels has been described previously after the interruption of the optic nerve far from the RGC somata (McKerracher et al., 1993), and following a distal lesion of the rubrospinal tract (Tetzlaff et al., 1991). The present finding of a decrease in the $\beta$-tubulin mRNA level after RGC axotomy near the eye suggests that such an early and transient rise in tubulin mRNA levels is not a standard response to CNS damage. Furthermore, the magnitude of the fall in mRNAs observed in the axotomized nonregenerating RGCs differed with the site of injury: a month after RGC axons were interrupted in the optic nerve $9 \mathrm{~mm}$ from the eye, the NF-M and $\beta$-tubulin levels were, respectively, $70 \%$ and $80 \%$ of normal (McKerracher et al., 1993); on the other hand, when the RGC axons were severed only $0.5 \mathrm{~mm}$ from the retina, these values averaged $50 \%$ and $60 \%$. The differences in NF-M and $\beta$-tubulin mRNAs documented here after lesions near and far from the $\mathrm{RGC}$ somata provide an additional example of the range of changes in gene expression that are possible in damaged CNS ncurons of adult mammals.

We have previously documented that when the optic nerve is transected close to the eye of adult rats, more than $80 \%$ of the axotomized RGCs die within 2 weeks of injury while only $20 \%$ of such cells are usually lost if the damage is inflicted 9 $10 \mathrm{~mm}$ from the retina (Berkelaar et al., 1992; Villegas-Perez et al., 1993). Furthermore, a regeneration of $\mathrm{RGC}$ axons into $P N$ grafts has only been documented when the PN segments are attached to the optic nerve stump near the eye (Aguayo et al., 1991). While the determinants of the various levels of gene expression documented in this study remain unknown, the striking differences in the survival and regrowth of axotomized RGCs that are associated with lesions at various sites along the optic nerve (Richardson et al., 1984; Aguayo et al., 1991; VillegasPerez et al., 1993) suggest that these variations reflect biological mechanisms of importance to the understanding of the various responses of injured CNS neurons.

\section{References}

Acheson A, Barker PA, Alderson RF, Miller FD, Murphy RA (1991) Detection of brain-derived neurotrophic factor-like activity in fibroblasts and Schwann cells: inhibition by antibodies to NGF. Neuron 7:265-275.

Aguayo AJ, Rasminsky M, Bray GM, Carbonetto S, McKerracher L, Villegas-Perez MP, Vidal-Sanz M, Carter DA (1991) Degenerative and regenerative responses of injured neurons in the central nervous system of adult mammals. Philos Trans R Soc Lond [Biol] 331:337343.

Atashi JR, Klinz SG, Ingraham CA, Matten WT, Schachner M, Maness PF (1992) Neural cell adhesion molecules modulate tyrosine phos- phorylation of tubulin in nerve growth cone membranes. Neuron 8:831-842.

Berkelaar M, Cohen A, Bray GM, Aguayo AJ (1992) Effects of optic nerve cut or crush on the short and long-term survival of rat retinal ganglion cells. Soc Neurosci Abstr 18:48.

Cleveland DW (1988) Autoregulated instability of tubulin mRNAs: a novel eukaryotic regulatory mechanism. Trends Biol Sci 13:339343.

Grafstein B (1986) The retina as a regenerating organ. In: The retina: a model for cell biology studies, Vol 2 (Adler R, Farker D, eds), pp 275-335. New York: Academic.

Heumann R, Lindholm D, Bandtlow C, Mayer M, Radeke MJ, Misko TP, Shooter E, Thoenen $H$ (1987) Differential regulation of nerve growth factor (NGF) and NGF-receptor mRNA in the rat sciatic nerve during development, degeneration, and regeneration; role played by macrophages. Proc Natl Acad Sci USA 84:8735-8739.

Hoffman PN, Cleveland DW (1988) Neurofilament and tubulin expression recapitulates the developmental program during axonal regeneration: induction of a specific $\beta$-tubulin isotype. Proc Natl Acad Sci USA 85:4530-4533.

Hoffman PN, Cleveland DW, Griffin JW, Landes PW, Cowan NJ, Price DL (1987) Neurofilament gene expression: a major determinant of axonal caliber. Proc Natl Acad Sci USA 84:3472-3476.

Julien J-P, Meyer D, Flavell D, Hurst J, Grosveld F (1986) Cloning and developmental expression of the murine neurofilament gene family. Mol Brain Res 1:243-250.

Lewis SA, Gwo-Shu Lee M, Cowan NJ (1985) Five mouse tubulin isotypes and their regulated expression during development. J Cell Biol 101:852-861.

Ma Y, Campenot RB, Miller FD (1992) Concentration-dependent regulation of neuronal gene expression by nerve growth factor. J Cell Biol 117:135-141.

Mansour-Robaey S, Bray GM, Aguayo AJ (1992) In vivo effects of brain-derived neurotrophic factor (BDNF) and injury on the survival of axotomized retinal ganglion cells (RGCs) in adult rats. Mol Biol Cell 3:333a.

McKerracher L, Vidal-Sanz M, Aguayo AJ (1990a) Slow transport rates of cytoskeletal proteins change during regeneration of axotomized retinal neurons in adult rats. J Neurosci 10:641-648.

McKerracher L, Vidal-Sanz M, Essagian C, Aguayo AJ (1990b) Selective impairment of slow axonal transport after optic nerve injury in adult rats. $J$ Neurosci 10:2834-2841.

McKerracher L, Essagian C, Aguayo AJ (1993) Temporal changes in $\beta$-tubulin and neurofilament mRNA levels after transection of adult rat retinal ganglion cell axons in the optic nerve. J Neurosci 13:26172626.

Meyer M, Matsuoka I, Wetmore C, Olson L, Thoenen H (1992) Enhanced synthesis of brain-derived neurotrophic factor in the lesioned peripheral nerve: different mechanisms are responsible for the regulation of BDNF and NGF mRNA. J Cell Biol 119:45-54.

Mikucki SA, Oblinger MM (1991) Corticospinal neurons exhibit a novel pattern of cytoskeletal gene expression after injury. J Neurosci Res 30:213-225.

Miller FD, Tetzlaff W, Bisby MA, Fawcett JW, Milner RJ (1989) Rapid induction of the major embryonic $\alpha$-tubulin mRNA, T $\alpha 1$, during nerve regeneration in adult rats. J Neurosci 9:1452-1463.

Mizobuchi T, Yagi Y, Mizuno A (1990) Changes in $\alpha$-tubulin and actin gene expression during optic nerve regeneration in frog retina. J Neurochem 55:54-59.

Perry VH (1981) Evidence for an amacrine cell system in the ganglion cell layer of the rat retina. Neuroscience 6:931-944.

Piechaczyk M, Blanchard JM, Marty L, Dani C, Panabieres F, El Sabouty S, Fort P, Jeanteur P (1984) Post-transcriptional regulation of glyceraldehyde-3-phosphate-dehydrogenase gene expression in rat tissues. Nucleic Acids Res 12:6951-6963.

Richardson PM, Issa VMK, Aguayo AJ (1984) Regeneration of long spinal axons in the rat. J Neurocytol 13:165-182.

Tetzlaff W, Alexander SW, Miller FD, Bisby MA (1991) Response of facial and rubrospinal neurons to axotomy: changes in mRNA expression for cytoskeletal proteins and GAP-43. J Neurosci 11:25282544.

Thanos S, Bahr M, Barde Y-A, Vanselow J (1989) Survival and axonal elongation of adult rat retinal ganglion cells. Eur J Neurosci 1:19-26.

Verge VMK, Tetzlaff W, Bisby MA, Richardson PM (1990) Influence of nerve growth factor on neurofilament gene expression in mature primary sensory neurons. J Neurosci 10:2018-2025. 
Vidal-Sanz M, Bray GM, Villegas-Perez MP, Thanos S, Aguayo AJ (1987) Axonal regeneration and synapse formation in the superior colliculus by retinal ganglion cells in the adult rat. J Neurosci 7:2894 2909.

Vidal-Sanz M, Villegas-Perez MP, Bray GM, Aguayo AJ (1988) Persistent retrograde labeling of adult rat retinal ganglion cells with the carbocyanine dye DiI. Exp Neurol 102:92-101.

Villegas-Perez MP, Vidal-Sanz M, Bray GM, Aguayo AJ (1988) Influences of peripheral nerve grafts on the survival and regrowth of axotomized retinal ganglion cells in adult rats. J Neurosci 8:265-280.
Villegas-Perez MP, Vidal-Sanz M, Rasminsky M, Bray GM, Aguayo AJ (1993) Rapid and protracted phases of retinal ganglion cell loss following axotomy in the optic nerve of adult rats. J Neurobiol 24: 23-26.

Wong J, Oblinger MM (1991) NGF rescues substance $P$ expression but not neurofilament or tubulin gene expression in axotomized sensory neurons. J Neurosci 11:543-552.

Zachary I, Rozengurt E (1992) Focal adhesion kinase (p125 $5^{\mathrm{FAK}}$ ): a point of convergence in the action of neuropeptides, integrins, and oncogenes. Cell 71:891-984. 